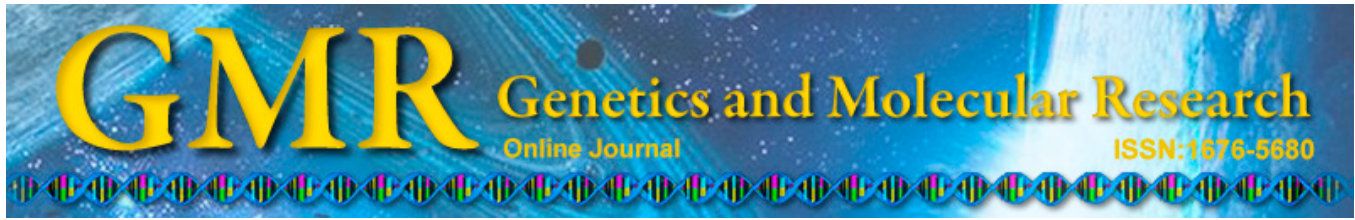

\title{
Effect of Fimbristylis ovata on receptor for advanced glycation end-products, proinflammatory cytokines, and cell adhesion molecule level and gene expression in U937 and bEnd.3 cell lines
}

\author{
S. Sukjamnong and R. Santiyanont \\ Department of Clinical Chemistry, Faculty of Allied Health Sciences, \\ Chulalongkorn University, Bangkok, Thailand \\ Corresponding author: R. Santiyanont \\ E-mail: rachana.s@chula.ac.th
}

Genet. Mol. Res. 14 (2): 3984-3994 (2015)

Received May 29, 2014

Accepted October 17, 2014

Published April 27, 2015

DOI http://dx.doi.org/10.4238/2015.April.27.13

\begin{abstract}
Fimbristylis ovata has been long used as a traditional medicine for chronic inflammatory diseases; however, there are no data regarding its anti-inflammatory properties. In this study, we investigated the effects of $F$. ovata extracts on the secretion of pro-inflammatory cytokines, cell adhesion molecule, and receptor for advanced glycation end-products (RAGE) in lipopolysaccharide-stimulated cells. F. ovata was extracted using the maceration method with 3 different solvents: ethanol, methanol, and water. The effect of $F$. ovata extracts on cell viability was evaluated using the MTT assay. Pro-inflammatory cytokines and cell adhesion molecules were investigated by reverse transcription-polymerase chain reaction and an enzyme-linked immunosorbent assay. Upon incubation with $F$. ovata extracts up to 100 $\mu \mathrm{g} / \mathrm{mL}$, cell viability was more than $80 \%$. F. ovata extracts could inhibit interleukin-6 level and gene expression as well as the RAGE gene in the
\end{abstract}


monocytic cell lineU937. Moreover, the results showed that vascular cell adhesion molecule 1 secretion and gene expression were decreased when lipopolysaccharide-activated brain endothelial cells (bEnd.3) were treated with $F$. ovata extracts. Therefore, the anti-inflammatory activity of $F$. ovata extracts may result from their inhibitory actions via the RAGE signaling pathway.

Key words: bEnd.3; Cell adhesion molecule; Fimbristylis ovata; U937; Proinflammatory cytokines; Random activation of gene expression

\section{INTRODUCTION}

Chronic inflammation is a major cause of chronic degenerative diseases, including rheumatoid arthritis, systemic lupus erythematosus, cardiovascular disease, cancer, and type 2 diabetes mellitus. Several studies have demonstrated that excessive production of pro-inflammatory cytokines and chemokines are involved in the pathogenesis of these diseases (Sweeney and Firestein, 2004; Davis et al., 2008; King, 2008; Van den Oever et al., 2010). Furthermore, upregulation of adhesion molecules in endothelial cells during leukocyte recruitments associated with the progression of atherosclerosis and systemic lupus erythematosus (Ballantyne and Nambi, 2005; Rhew and Ramsey-Goldman, 2006). Endothelial dysfunction plays a role in the development of diabetic complications (Esper et al., 2008). Several studies have found that activation of receptor for advanced glycation end-products (RAGE) contributes to inflammation, development of diabetic complications, and cardiovascular disease (Lukic et al., 2008; Yan et al., 2009). Activation of RAGE has been demonstrated to mediate various intracellular pathways, including phosphoinositide 3-kinase/AKT, mitogen-activated protein kinase, and nuclear factor (NF)- $\mathrm{kB}$, which lead to the secretion of pro-inflammatory cytokines (Lin et al., 2009).

An increasing number of studies have reported novel therapeutic interventions for chronic inflammatory diseases. Accumulating evidence revealed that anti-interleukin-6 (IL-6) therapies and blockade of the IL-6 receptor using a neutralizing monoclonal antibody may suppress chronic inflammation in degenerative diseases, such as some types of cancers (Tawara et al., 2011), rheumatoid arthritis, Castleman's disease, and juvenile idiopathic arthritis (Neurath and Finotto, 2011). Another study indicated that inhibition of tumor necrosis factoralpha $(\mathrm{TNF}-\alpha)$ receptor and chimeric monoclonal antibody TNF- $\alpha$ can be used to treat diabetic complications (Navarro-González et al., 2009). Moreover, TNF- $\alpha$ inhibitors are available for treating rheumatoid arthritis (Thalayasingam and Isaacs, 2011). It was previously shown that blocking of IL-1 $\beta$ activity could reduce the severity of acute and chronic auto-inflammatory diseases. The IL-1 receptor antagonist was approved for treatment of rheumatoid arthritis and type 2 diabetes mellitus (Dinarello, 2011). The soluble extracellular domain of RAGE can be used as a potential therapeutic blocker in the treatment of diabetic macro vascular diseases and cardiovascular diseases (Park et al., 1998). We also found that alternately spliced RAGEv1 or soluble RAGE can decrease the expression of NF- $\kappa B$ and TNF- $\alpha$ in HepG2 cells, suggesting that it also has a therapeutic effect in hepatic cancer (Lertwittayapon et al., 2012). Recent studies have shown that glucagon-like peptide-1, a therapeutic target for the treatment of patients with type 2 diabetes, may downregulate vascular cell adhesion molecule 1 (VCAM-1) mRNA levels by reducing RAGE gene expression (Ishibashi et al., 2010). Traditional Chinese medicine used for treating inflammatory processes and atherosclerosis may reduce VCAM-1 
gene expression (Kwon et al., 2007). Many Thai herbs have been used for therapeutic purposes in traditional medicine. Several studies have demonstrated that Boesenbergia rotunda (L.) Mansf. has an anti-inflammatory effect, which may be derived from its active flavonoid derivatives (Tuchinda et al., 2002; Ching et al., 2007). Lagerstroemia speciosa (L.) and Piper sarmentosum Roxb. exert pharmacological effects such as anti-inflammatory effects and antioxidant activity (Priya et al., 2008; Hussain et al., 2009).

Fimbristylis ovata (Burm.f.) Kern., known by its common name flat spike sedge or "Ya-sae-ma" in Thai, belongs to the family Cyperaceae (Simpson and Koyama, 1998). Plants in the family Cyperaceae consist of several components such as phenolic compounds, flavonoids, alkaloid, glycoside proteins, amino acids, tannins, and saponins (Chaulya et al., 2010, 2011). Our previous study demonstrated that $F$. ovata has antioxidant activity and inhibits RAGE gene expression in a human lung adenocarcinoma epithelial cell line (Sukjamnong and Santiyanont, 2012). Moreover, F. ovata has been long used for treating adenitis, scrofula, syphilis, cough, bronchitis, and asthma (Burkill et al., 1985; Khare, 2007), but the underlying mechanism of its therapeutic activity is unknown. The aim of this study was to investigate the effects of $F$. ovata extracts on the secretion of pro-inflammatory cytokines, cell adhesion molecules, and activation of RAGE in lipopolysaccharide (LPS)-stimulated cells.

\section{MATERIAL AND METHODS}

\section{Plant material}

F. ovata was collected from a single source in Bangkok, Thailand, and identified by Professor Kasin Suvatabhandhu of the Herbarium, Department of Botany, Faculty of Science, Chulalongkorn University, Thailand, voucher No. 013431(BCU). The fresh plant (stem and flower) was cleaned with water, cut into short pieces, dried in a laboratory oven at $45^{\circ} \mathrm{C}$ for 5 days, and finally ground into a fine powder. The plant powder was extracted with 1:10 $(\mathrm{v} / \mathrm{v})$ ethanol or $1: 10(\mathrm{v} / \mathrm{v})$ methanol by maceration in a shaking incubator at $37^{\circ} \mathrm{C}$ for $72 \mathrm{~h}$. The extract was filtered and processing was repeated twice, and all filtered extracts were collected and evaporated using a rotatory evaporator. The plant powder was also extracted with 1:10 (v/v) water by boiling at $100^{\circ} \mathrm{C}$ for $2 \mathrm{~h}$ followed by lyophilization. Crude extracts were dissolved in dimethyl sulfoxide and maintained as $100 \mathrm{mg} / \mathrm{mL}$ stock solutions at $-20^{\circ} \mathrm{C}$ and protected from light.

\section{Cell culture}

Human monocytic cells (U937) were cultured in RPMI 1640 medium supplemented with $10 \%$ fetal bovine serum, $100 \mathrm{U} / \mathrm{mL}$ penicillin, and $100 \mu \mathrm{g} / \mathrm{mL}$ streptomycinin in a humidified atmosphere with $5 \% \mathrm{CO}_{2}$ at $37^{\circ} \mathrm{C}$. Mouse brain endothelial cells (bEnd.3) were cultured under the same conditions except that the medium used was Dulbecco's modified Eagle medium (DMEM-high glucose, Gibco, Grand Island, NY, USA).

\section{MTT assay for cell viability}

Cell viability was determined using the MTT assay (Wang et al., 2011) to measure mi- 
tochondrial dehydrogenase enzyme activity that reduces 3-(4,5-dimethyl-triazolyl-2-yl)-2,5diphenyl tetrazolium bromide to purple formazan. Cells were seeded on 96-well plates at a density of $5 \times 10^{3}$ cells/well and incubated in a humidified $5 \% \mathrm{CO}_{2}$ incubator at $37^{\circ} \mathrm{C}$ for $24 \mathrm{~h}$. Cells without $F$. ovata extracts were used as a negative control and considered as $100 \%$ viable. F. ovata extracts were added and incubated for $24 \mathrm{~h}$. Next, $20 \mu \mathrm{L} 0.5 \mathrm{mg} / \mathrm{mL}$ MTT was added and the plates were incubated for $4 \mathrm{~h}$ in a humidified $5 \% \mathrm{CO}_{2}$ at $37^{\circ} \mathrm{C}$. The culture medium was removed and $200 \mu \mathrm{L}$ dimethyl sulfoxide was added to dissolve the formazan crystals. Absorbance was measured at $550 \mathrm{~nm}$ using a microplate reader. The percentage of cell viability was calculated based on the following formula:

$\%$ cell viability $=[($ absorbance of treatment group - blank $) /$ (absorbance of control group - blank)] x 100.

\section{Enzyme-linked immunosorbent assay (ELISA)}

U937 cells were seeded at a density of $5 \times 10^{5}$ cells $/ \mathrm{mL}$ on 24 -well plates and $10 \mathrm{ng} / \mathrm{mL}$ phorbol 12-myristate 13-acetate was added to activate the differentiation of cells into macrophages (Grkovich et al., 2006). F. ovata extracts were added and the cells were incubated for $6 \mathrm{~h}$, then 1 $\mu \mathrm{g} / \mathrm{mL}$ LPS was added and the cells were incubated for $24 \mathrm{~h}$. The supernatants were collected and stored at $-20^{\circ} \mathrm{C}$. The cultured supernatants were measured for human TNF- $\alpha$, human IL- $1 \beta$, and human IL-6 using an ELISA kit (R\&D Diagnostics, Minneapolis, MN, USA) according to the manufacturer protocol.

bEnd. 3 cells were seeded at a density of $5 \times 10^{5}$ cells $/ \mathrm{mL}$ on 24 -well plates. $F$. ovata extracts were added and the cells were incubated for $6 \mathrm{~h}$. Next, $1 \mu \mathrm{g} / \mathrm{mL}$ LPS was added and the cells were incubated for $24 \mathrm{~h}$. The supernatants were collected and stored at $-20^{\circ} \mathrm{C}$. The cultured supernatants were measured for mouse VCAM-1 using the ELISA kit as described above.

\section{Reverse-transcription polymerase chain reaction analysis}

U937 cells were seeded in density of $1 \times 10^{6}$ cells $/ \mathrm{mL}$ in 6 -well plates and $10 \mathrm{ng} / \mathrm{mL}$ phorbol 12-myristate 13-acetate was added to differentiate cells into macrophages. bEnd.3 cells were seeded at a density of $1 \times 10^{6}$ cells $/ \mathrm{mL}$ in 6 -well plates. F. ovate was added and the cells were incubated for $6 \mathrm{~h}$, then $1 \mu \mathrm{g} / \mathrm{mL}$ LPS was added and the cells were incubated for $24 \mathrm{~h}$. Total RNA was extracted from the cells using Tri-RNA reagent (Favorgen Biotech Corp., Taiwan, China) according to manufacturer instructions. RNA was treated with deoxyribonuclease I (DNase I; Promega, Madison, WI, USA). DNase I-treated RNA was reverse transcribed using the ImProm-II Reverse Transcription System (Promega) following the manufacturer protocol. For the amplification reaction, a polymerase chain reaction mixture composed of $5 \mu \mathrm{L}$ reverse transcription reaction mixture, $10 \mathrm{X}$ Taq buffer, $1.0 \mathrm{mM} \mathrm{MgCl}, 10 \mathrm{mM}$ dNTPs, $10 \mu \mathrm{M}$ primers, and 1.25 U Taq DNA polymerase (Fermentas, Vilnius, Lithuania) was used. To amplify cDNA, each desired DNA fragment was amplified for 35 cycles using each gene-specific primer pair listed in Table 1 (Jang et al., 2006; Park et al., 2009). The product was separated on a $2 \%$ agarose gel, stained with ethidium bromide, and visualized using a gel documentation system (SynGene, UK). 
Table 1. List of gene-specific primers for reverse transcription-polymerase chain reaction.

\begin{tabular}{|c|c|c|c|c|}
\hline Gene & & Sequence & Annealing temp $\left({ }^{\circ} \mathrm{C}\right)$ & Product size (bp) \\
\hline$\beta$-actin & $\begin{array}{l}\text { Forward primer } \\
\text { Reverse primer }\end{array}$ & $\begin{array}{l}\text { 5' ACGGGTCACCACACTGTGC 3' } \\
\text { 5' CTAGAAGCATTTGCGGTGGACGATG 3' }\end{array}$ & 58 & 656 \\
\hline$I L-1 \beta$ & Forward primer & $\begin{array}{l}\text { 5' CTAGAAGCATTTGCGGTGGACGATG 3' } \\
\text { 5' AGCCATGGCAGAAGTACCT 3' }\end{array}$ & 50 & 823 \\
\hline & Reverse primer & 5' CAGCTCTCTTTAGGAAGACAC 3' & & \\
\hline IL-6 & $\begin{array}{l}\text { Forward primer } \\
\text { Reverse primer }\end{array}$ & $\begin{array}{l}\text { 5' ATGAACTCCTTCTCCACAAGCGC 3' } \\
\text { 5' GAAGAGCCCTCAGGCTGGACTG 3' }\end{array}$ & 50 & 252 \\
\hline$T N F-\alpha$ & $\begin{array}{l}\text { Forward primer } \\
\text { Reverse primer }\end{array}$ & $\begin{array}{l}\text { 5' TCTCGAACCCCGAGTGACAA 3' } \\
\text { 5' TGAAGAGGACCTGGGAGTAG 3' }\end{array}$ & 55 & 181 \\
\hline$V C A M$ & $\begin{array}{l}\text { Forward primer } \\
\text { Reverse primer }\end{array}$ & $\begin{array}{l}\text { 5' AGGCACAGCTGCAGGATGCC 3' } \\
\text { 5' GGAGGGGGCGGGGCTGTAAT 3' }\end{array}$ & 59 & 333 \\
\hline$R A G E$ & $\begin{array}{l}\text { Forward primer } \\
\text { Reverse primer }\end{array}$ & $\begin{array}{l}\text { 5' GTGGGGACATGTGTGTCAGAGGGAA 3' } \\
\text { 5' TGAGGAGAGGGCTGGGCAGGGACT 3' }\end{array}$ & 65 & 383 \\
\hline
\end{tabular}

\section{Statistical analysis}

Data are reporetd as means \pm standard error of the mean of 3 experiments. Statistically significant differences were determined by one-way analysis of variance followed by a posthoc Tukey test. Differences were considered statistically significant when $\mathrm{P} \leq 0.05$.

\section{RESULTS}

\section{Effect of $F$. ovata extracts on cell viability in $\mathrm{U} 937$ and bEnd.3 cells}

Based on the results of the MTT assay, upon incubation of U937 and bEnd.3 cells with various concentrations of $F$. ovata extracts for $24 \mathrm{~h}$, the extracts showed no significant effect on cell viability of $\mathrm{U} 937$ and bEnd.3 in the concentration range $0.19-100 \mu \mathrm{g} / \mathrm{mL}$. Cell viability was greater than $80 \%$ (Figure 1).

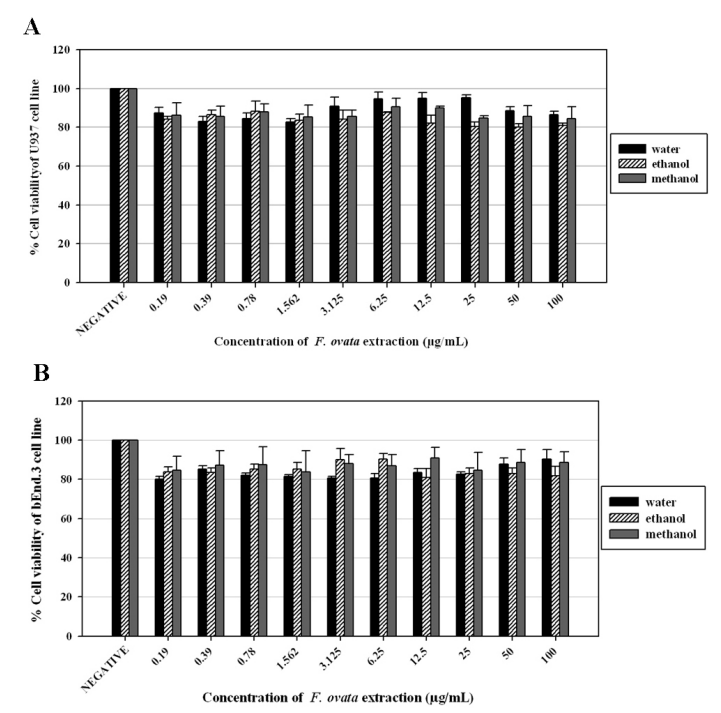

Figure 1. Cell viability was determined using the MTT assay. Cells were incubated with $F$. ovata extracted by water, ethanol, and methanol. A. U937; B. bEnd.3. Negative included cells without $F$. ovata extracts. Data are reported as means \pm standard error of the mean of triplicate measurements. 


\section{Effects of $F$. ovata extracts on proinflammatory cytokines and adhesion molecule levels}

Proinflammatory cytokines and adhesion molecule levels were measured using ELISA. After incubating the cells with various concentrations of $F$. ovata extracts for $24 \mathrm{~h}$, we found that IL-6 and VCAM-1 concentrations were significantly decreased $(\mathrm{P} \leq 0.05)$ compared with the control cells that had not been exposed to the extracts, as shown in Figures 2 and 3.
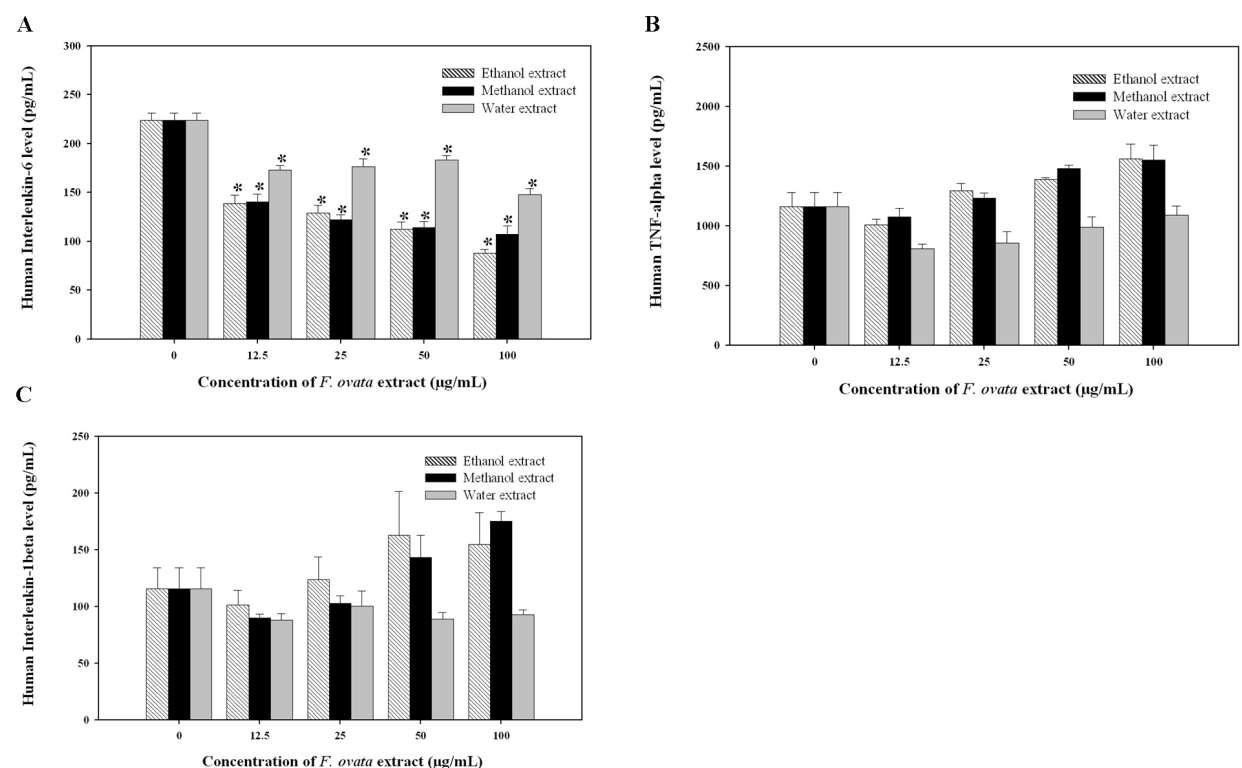

Figure 2. Effect of Fimbristylis ovata extracts on IL-6 (A), TNF- $\alpha(\mathbf{B})$, and IL-1 $\beta$ (C) secretion in LPS-stimulated U937 cells compared for extract-treated cells and non-treated control cells. Data are reported as means \pm standard error of the mean for triplicate measurements $(* \mathrm{P} \leq 0.05)$

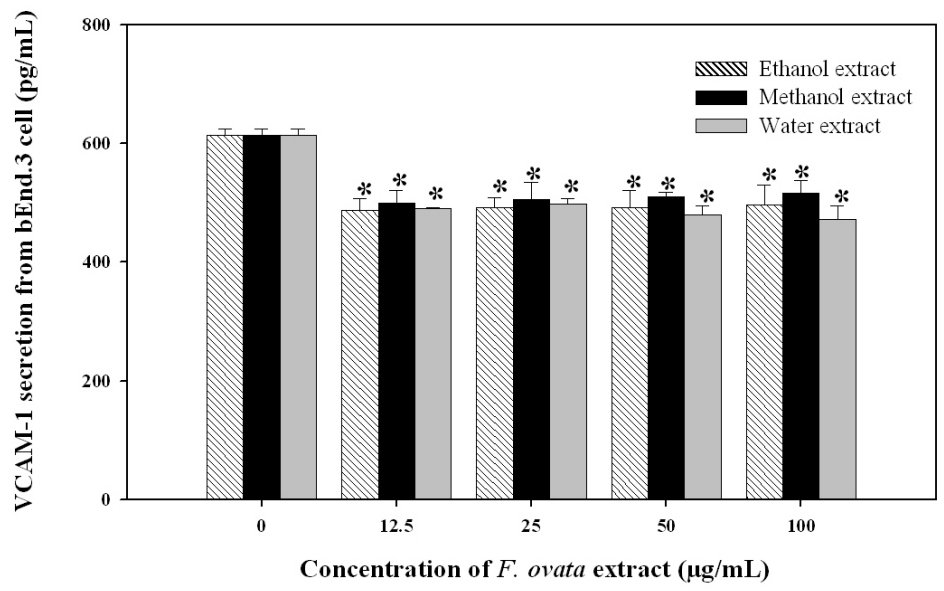

Figure 3. Effect of Fimbristylis ovata extracts on VCAM-1 secretion in LPS-stimulated bEnd.3 cells compared for extract-treated cells and non-treated control cells. Data are reported as means \pm standard error of the mean for triplicate measurements $(* \mathrm{P} \leq 0.05)$. 


\section{F. ovata extracts downregulate gene expression of $I L-6, R A G E$, and $V C A M-1$, but not of $T N F-\alpha$ and $I L-1 \beta$}

Gene expression was determined by reverse-transcription polymerase chain reaction. After incubating U937 cells with various concentrations of $F$. ovata extracts for $24 \mathrm{~h}, I L-6$ and $R A G E$ gene expression were significantly decreased $(\mathrm{P} \leq 0.05)$ compared with the control cells. However, $T N F-\alpha$ and $I L-1 \beta$ mRNA expression did not decrease, as shown in Figures 4 and 5. Regarding the effect of $F$. ovata extracts on cell adhesion molecule in endothelial cells, after bEnd. 3 cells were incubated with $F$. ovata ethanol and methanol extracts for $24 \mathrm{~h}$, $V C A M-1$ gene expression was significantly decreased $(\mathrm{P} \leq 0.05)$ compared with the control cells (Figure 6).
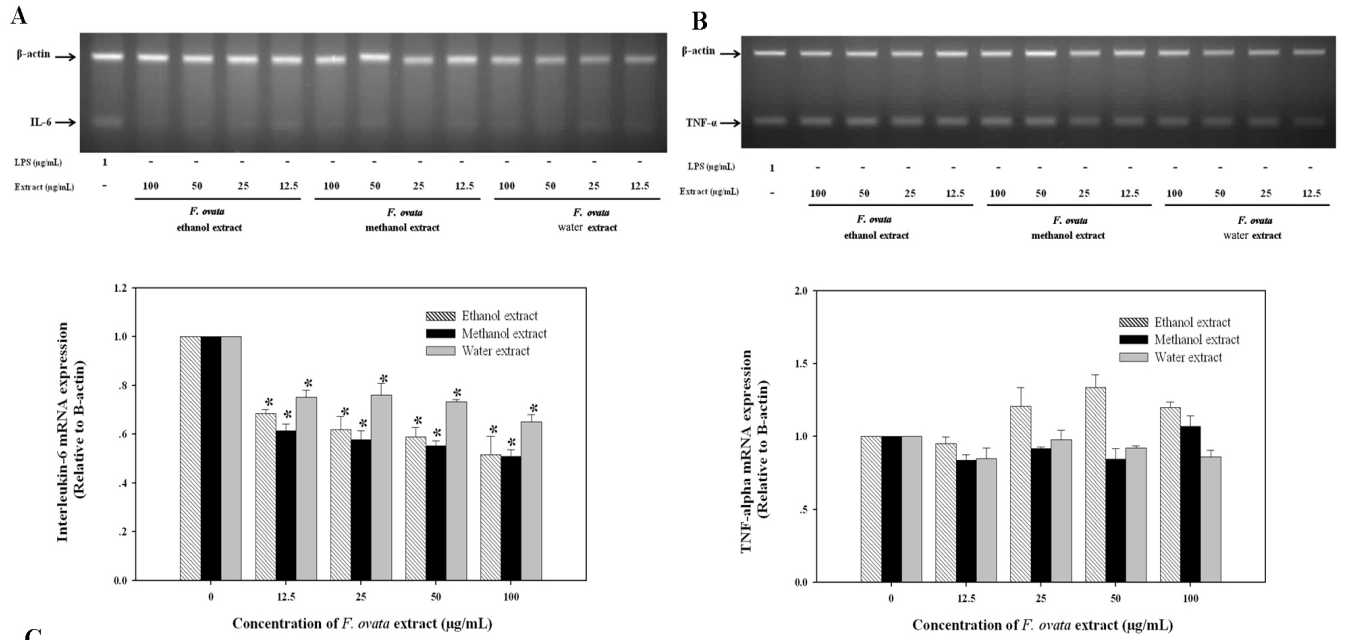

C
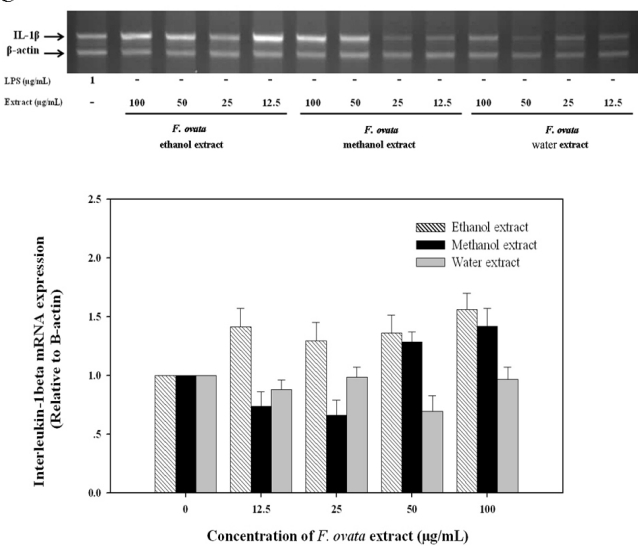

Figure 4. Effect of Fimbristylis ovata extracts on $I L-6, T N F-\alpha$, and $I L-1 \beta$ gene expression in LPS-stimulated U937 cells compared for extract-treated cells and non-treated cells. A. IL-6; B. TNF- $\alpha$; C. IL-1 $\beta$. $\beta$-actin was used for normalization. Data are reported as means \pm standard error of the mean of triple measurements $(* \mathrm{P} \leq 0.05)$. 

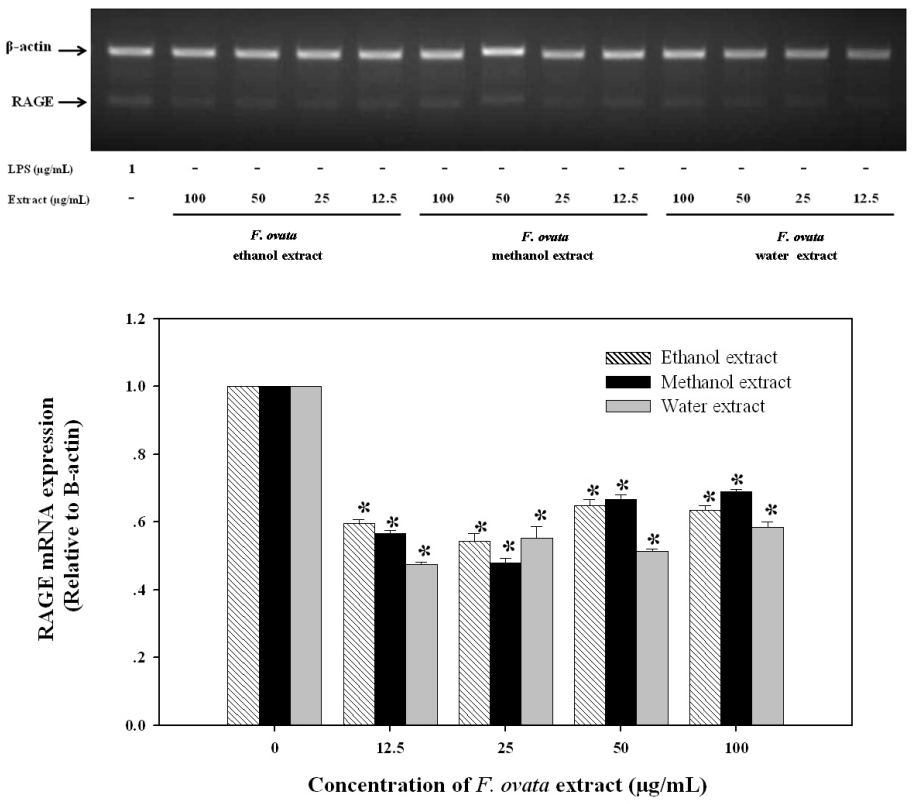

Figure 5. Effect of Fimbristylis ovata extracts on RAGE gene expression in LPS-stimulated U937 cells compared for extract-treated cells and non-treated cells. $\beta$-actin was used for normalization. Data are reported as means \pm standard error of the mean of triplicate measurements $(* \mathrm{P} \leq 0.05)$.
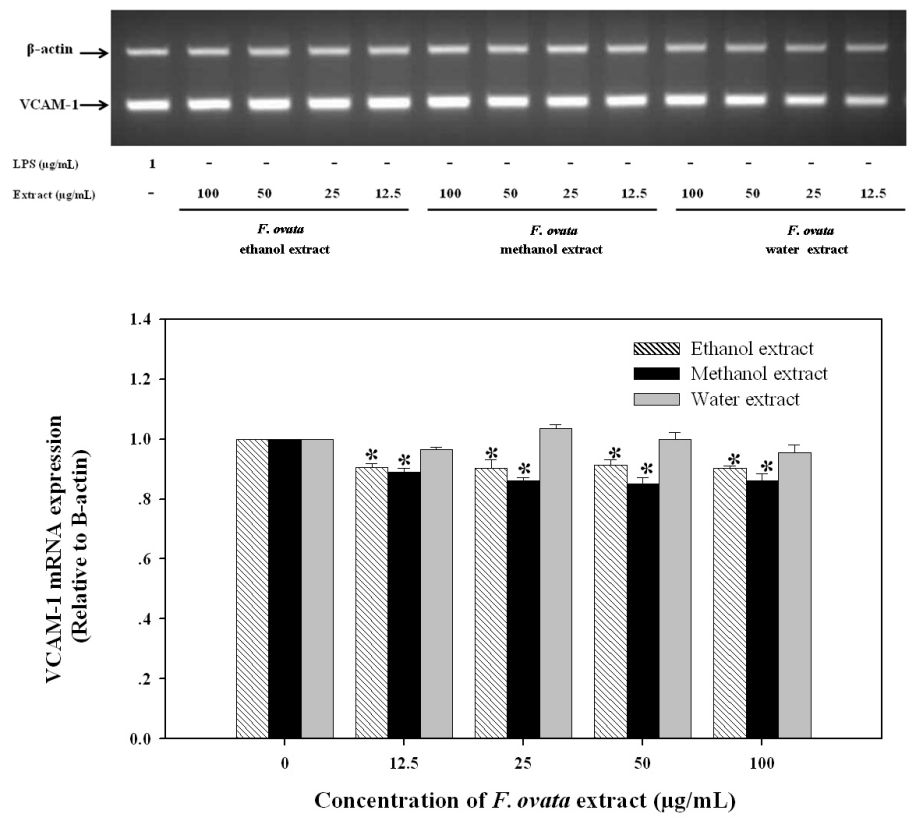

Figure 6. Effect of Fimbristylis ovata extracts on VCAM-1 gene expression in LPS-stimulated bEnd.3 cells compared for extract-treated cells and non-treated cells. $\beta$-actin was used for normalization. Data are reported as means \pm standard error of the mean for triplicate measurements $(* \mathrm{P} \leq 0.05)$. 


\section{DISCUSSION}

This is the first report of the possible anti-inflammatory mechanism and therapeutic effect of $F$. ovata. There was no difference in cell viability after treating cells with various extracts of $F$. ovata. Production of the pro-inflammatory cytokine IL-6 in U937 cells was significantly decreased in a dose-dependent manner with $F$. ovata extracts using water, ethanol, and methanol. At concentrations of $12.5-100 \mu \mathrm{g} / \mathrm{mL}$, the extracts of all solvents inhibited $I L-6$ mRNA expression in a dose-dependent manner, but did not reduce TNF- $\alpha$ or IL-1 $\beta$ secretion and mRNA expression. In addition, production of the cell adhesion molecule VCAM-1 in bEnd.3 cells was significantly decreased by the extracts at concentrations of $12.5-100 \mu \mathrm{g} /$ $\mathrm{mL}$, which has been demonstrated for both secretion and mRNA expression. Importantly, these concentrations of $F$. ovata extracts also inhibited $R A G E$ mRNA expression. Activation of RAGE transduced cell surface signals involved in various intracellular pathways, including phosphoinositide 3-kinase/AKT, mitogen-activated protein kinase, and NF- $\mathrm{KB}$ (Lin et al., 2009). Additional studies demonstrated that the expression of IL-6 was induced through RAGE-activated pathways, including NF- $\mathrm{KB}$ and mitogen-activated protein kinase signaling pathways (Rasheed et al., 2011). Moreover, activation of RAGE has been shown to induce expression of VCAM-1 by the NF-kB signaling pathway (Schmidt et al., 1995). Therefore, $F$. ovata extracts may play a protective role against inflammation by suppressing gene expression and producing pro-inflammatory cytokines as well as cell adhesion molecules by downregulating $R A G E$ gene expression (Kwon et al., 2007; Ishibashi et al., 2010). Kimura et al. (2005) reported that LPS directly activated Jak2 and Stat5, resulting in specific recruitment of Stat 5 to the $I L-6$ promoter together with the NF- $\kappa \mathrm{B}$ p50 subunit. Evidence suggests that $\mathrm{I} \kappa \mathrm{B} \zeta$ associated with the NF- $\kappa B$ p50 subunit activates the promoter region of $I L-6$ (Lu et al., 2008). In addition, transcription factor CCAAT enhancer binding protein $\beta$ has been shown to be critically involved in regulating IL-6 production (Bretz et al., 1994). Based on this study, the effect of $F$. ovata extracts on the secretion of IL-6 may be related to its inhibitory actions via the RAGE signaling pathway, Jak2-Stat5 pathway, IкB $\zeta$, and CCAAT enhancer binding protein $\beta$. Additional studies are necessary to elucidate the effect of $F$. ovata extracts on the regulation of these signaling pathways. In conclusion, our results showed that $F$. ovate not only suppressed cytokine and cell adhesion molecule secretion, but also inhibited RAGE expression. This suggests that $F$. ovata may be useful for treating chronic inflammation. However, the effect of $F$. ovata on downstream signaling of the RAGE signaling pathway should be further examined.

\section{ACKNOWLEDGMENTS}

Research financially supported by the 90th Anniversary of Chulalongkorn University Fund (Ratchadaphiseksomphot Endowment Fund) and the Center of Excellence in OmicsNanomedical Technology Development Project. We thank Dr. Lertyot Treeratanapiboon, Faculty of Medical Technology, Mahidol University, and Dr. Supantitra Chanprasert, Faculty of Allied Health Sciences, Chulalongkorn University for the generous gift of bEnd.3 cells and U937 cells.

\section{REFERENCES}

Ballantyne C and Nambi V (2005). Markers of inflammation and their clinical significance. Atherosclerosis Suppl. 6: 21-29. Bretz JD, Williams SC, Baer M, Johnson PF, et al. (1994). C/EBP-related protein 2 confers lipopolysaccharide-inducible expression of interleukin 6 and monocyte chemoattractant protein 1 to a lymphoblastic cell line. Proc. Natl. Acad. 
Sci. U. S. A. 91: 7306-7310.

Burkill HM, Dalziel JM and Hutchinson J (1985). The Useful Plants of West Tropical Africa. 2nd ed. Kew: Royal Botanic Gardens, London.

Chaulya NC, Haldar PK and Mukherjee A (2010). Sedative properties of methanol extract of rhizome of Cyperustegetum Roxb. J. Pharmacogn. Phytochem. 2: 40-43.

Chaulya NC, Haldar PK and Mukherjee A (2011). Antidiarrhoeal activity of methanol extract of the rhizomes of Cyperustegetum Roxb. Int. J. Pharm. Sci. 3: 133-135.

Ching AYL, Tang SW, Sukari MA, Lian GEC, et al. (2007). Characterization of flavonoid derivatives from Boesenbergia rotunda (L.). Malays. J. Anal. Sci. 11: 154-159.

Davis MC, Zautra AJ, Younger J, Motivala SJ, et al. (2008). Chronic stress and regulation of cellular markers of inflammation in rheumatoid arthritis: implications for fatigue. Brain Behav. Immun. 22:24-32.

Dinarello CA (2011). Blocking interleukin-1 $\beta$ in acute and chronic autoinflammatory diseases. J. Intern. Med. 269: 16-28.

Esper RJ, Vilarino JO, Machado RA and Paragano A (2008). Endothelial dysfunction in normal and abnormal glucose metabolism. Adv. Cardiol. 45: 17-43.

Grkovich A, Johnson CA, Buczynski MW and Dennis EA (2006). Lipopolysaccharide-induced cyclooxygenase-2 expression in human U937 macrophages is phosphatidic acid phosphohydrolase-1-dependent. J. Biol. Chem. 281: 32978-32987.

Hussain K, Ismail Z, Sadikun A and Ibrahim P (2009). Antioxidant, anti-TB activities, phenolic and amide contents of standardised extracts of Piper sarmentosum Roxb. Nat. Prod. Res. 23: 238-249.

Ishibashi Y, Matsui T, Takeuchi M and Yamagishi S (2010). Glucagon-like peptide-1 (GLP-1) inhibits advanced glycation end product (AGE)-induced up-regulation of VCAM-1 mRNA levels in endothelial cells by suppressing AGE receptor (RAGE) expression. Biochem. Biophys. Res. Commun. 391: 1405-1408.

Jang CH, Choi JH, Byun MS and Jue DM (2006). Chloroquine inhibits production of TNF-alpha, IL-1 beta and IL-6 from lipopolysaccharide-stimulated human monocytes/macrophages by different modes. Rheumatology 45: 703-710.

Khare CP (2007). Indian Medicinal Plants an Illustrated Dictionary. Springer, New York.

Kimura A, Naka T, Muta T, Takeuchi O, et al. (2005). Suppressor of cytokine signaling-1 selectively inhibits LPS-induced IL-6 production by regulating JAK-STAT. Proc. Natl. Acad. Sci. U. S. A. 102: 17089-17094.

King GL (2008). The role of inflammatory cytokines in diabetes and its complications. J. Periodontol. 79:1527-1534.

Kwon HM, Choi YJ, Choi JS, Kang SW, et al. (2007). Blockade of cytokine-induced endothelial cell adhesion molecule expression by licorice isoliquiritigenin through NF-kappaB signal disruption. Exp. Biol. Med. 232: 235-245.

Lertwittayapon T, Tencomnao T and Santiyanont R (2012). Inhibitory effect of alternatively spliced RAGEv1 on the expression of NF-kB and TNF- $\alpha$ in hepatocellular carcinoma cell line. Genet. Mol. Res. 11: 1712-1720.

Lin L, Park S and Lakatta EG (2009). RAGE signaling in inflammation and arterial aging. Front. Biosci. 14: 1403-1413.

Lu YC, Yeh WC and Ohashi PS (2008). LPS/TLR4 signal transduction pathway. Cytokine 42: 145-151.

Lukic IK, Humpert PM, Nawroth PP and Bierhaus A (2008). The RAGE pathway: activation and perpetuation in the pathogenesis of diabetic neuropathy. Ann. N. Y. Acad. Sci. 1126:76-80.

Navarro-González JF, Jarque A, Muros M, Mora C, et al. (2009). Tumor necrosis factor-alpha as a therapeutic target for diabetic nephropathy. Cytokine Growth Factor Rev. 20: 165-173.

Neurath MF and Finotto S (2011). IL-6 signaling in autoimmunity, chronic inflammation and inflammation-associated cancer. Cytokine Growth Factor Rev. 22: 83-89.

Park L, Raman KG, Lee KJ, Lu Y, et al. (1998). Suppression of accelerated diabetic atherosclerosis by the soluble receptor for advanced glycation end products. Nat. Med. 4: 1025-1031.

Park SL, Kim YM, Ahn JH, Lee SH, et al. (2009). Cadmium stimulates the expression of vascular cell adhesion molecule-1 (VCAM-1) via p38 mitogen-activated protein kinase (MAPK) and JNK activation in cerebrovascular endothelial cells. J. Pharmacol. Sci. 110: 405-409.

Priya TT, Sabu MC and Jolly CI (2008). Free radical scavenging and anti-inflammatory properties of Lagerstroemia speciosa (L). Inflammopharmacology 16:182-187.

Rasheed Z, Akhtar N and Haqqi TM (2011). Advanced glycation end products induce the expression of interleukin-6 and interleukin- 8 by receptor for advanced glycation end product-mediated activation of mitogen-activated protein kinases and nuclear factor- $\mathrm{\kappa B}$ in human osteoarthritis chondrocytes. Rheumatology 50: 838-851.

Rhew EYand Ramsey-Goldman R (2006). Premature atherosclerotic disease in systemic lupus erythematosus - role of inflammatory mechanisms. Autoimmun. Rev. 5: 101-105.

Schmidt AM, Hori O, Chen JX, Li JF, et al. (1995). Advanced glycation endproducts interacting with their endothelial receptor induce expression of vascular cell adhesion molecule-1 (VCAM-1) in cultured human endothelial cells and in mice. A potential mechanism for the accelerated vasculopathy of diabetes. J. Clin. Invest. 96: 1395-1403. 
Simpson DA and Koyama T (1998). Flora of Thailand Volume 6 Part 4: Cyperaceae. (Santisuk T and Larsen K, eds). Royal Forest Department, Bangkok.

Sukjamnong S and Santiyanont R (2012). Antioxidant activity of Fimbristylis ovata and its effect on RAGE gene expression in human lung adenocarcinoma epithelial cell line. J. Chem. Pharm. Res. 4:2483-2489.

Sweeney SE and Firestein GS (2004). Rheumatoid arthritis: regulation of synovial inflammation. Int. J. Biochem. Cell. Biol. 36: 372-378.

Tawara K, Oxford JT and Jorcyk CL (2011). Clinical significance of interleukin (IL)-6 in cancer metastasis to bone: potential of anti-IL-6 therapies. Cancer Manag. Res. 3: 177-189.

Thalayasingam N and Isaacs JD (2011). Anti-TNF therapy. Best Pract. Res. Clin. Rheumatol. 25: 549-567.

Tuchinda P, Reutrakul V, Claeson P, Pongprayoon U, et al. (2002). Anti-inflammatory cyclohexenylchalcone derivatives in Boesenbergia pandurata. Phytochemistry 59: 169-173.

van den Oever I, Raterman HG, Nurmohamed MT and Simsek S (2010). Endothelial dysfunction, inflammation, and apoptosis in diabetes mellitus. Mediat. Inflamm. 2010: 1-15.

Wang CZ, Zhang Y, Li XD, Hu Y, et al. (2011). PPAR $\gamma$ agonist suppresses TLR4 expression and TNF- $\alpha$ production in LPS stimulated monocyte leukemia cells. Cell. Biochem. Biophys. 60: 167-172.

Yan SF, Ramasamy R and Schmidt AM (2009). Receptor for AGE (RAGE) and its ligands-cast into leading roles in diabetes and the inflammatory response. J. Mol. Med. 87: 235-247. 